\title{
APPLICATION OF TRANEXAMIC ACID FOR THE PERIOPERATIVE PERIOD OF PATIENTS UNDERGOING SCOLIOSIS CORRECTION SURGERY
}

\author{
WENPENG LI $^{1 \#}$, JINGTAO GUAN $^{1 \#}$, YINGXUE GUO $^{2}$, JIAZHI WANG $^{3}$, YEQIU WANG $^{3}$, \\ YAN QU ${ }^{3 *}$ \\ ${ }^{1}$ Orthopeadic Surgery, The Second Affiliated Hospital of Jiamusi University, Jiamusi City 154002, Heilongjiang Province, China \\ ${ }^{2}$ Jiamusi University, Jiamusi City 154002, Heilongjiang Province, China \\ ${ }^{3}$ College of Jiamusi, Heilongjiang University of Chinese Medicine, Jiamusi City 154002, Heilongjiang Province, China
}

*corresponding author: doctor_quyanjiamusi@163.com

${ }^{*}$ Authors with equal contribution.

Manuscript received: February 2020

\begin{abstract}
This study aimed to investigate the efficacy of tranexamic acid (TXA) for the perioperative period of patients undergoing scoliosis correction surgery. 355 patients with scoliosis who were admitted to The Second Affiliated Hospital of Jiamusi University, China, from January 30, 2017, to January 30, 2019, were randomly divided into five groups: experimental group 1 (S1), experimental group 2 (S2), experimental group 3 (S3), experimental group 4 (S4) and control group (D0). Patients in experimental groups were treated with different doses of TXA $(15,30,45$ and $60 \mathrm{mg} / \mathrm{kg}$ bw) intravenously, 30 minutes before surgery and sustained infusion of $15 \mathrm{mg} / \mathrm{kg}$ bw/h TXA from the beginning until the end of the operation. Patients in D0 group received $30 \mathrm{mg} / \mathrm{kg}$ bw normal saline as control. Prothrombin time (PT), activated partial thromboplastin time (APTT), fibrinogen (FIB), thrombin time (TT), haemoglobin, platelet (PT), intraoperative blood loss and postoperative drainage volume in all groups were detected before and after the operation. Plasma levels of tumour necrosis factor- $\alpha$ (TNF- $\alpha$ ), interleukin-1 (IL-1), IL-6 and IL-8 were measured in S2 group and D0 group before, during and after the operation, and then, postoperative complications were recorded. The results showed that the PT, APTT and TT postoperative levels in D0 group were significantly increased compared with the levels in S2, S3 and S4 groups, and the FIB postoperative level significantly decrease compared with the level in S2, S3 and S4 groups. Postoperative levels of haemoglobin and PT in the D0 group were significantly lower compared with the levels in the S1, S2, S3 and S4 groups. The intraoperative blood loss and postoperative drainage volume in the S1 group were significantly increased compared with the levels from S2, S3 and S4 groups. The dose of $60 \mathrm{mg} / \mathrm{kg}$ bw TXA determines an increase of cases with complicated embolism compared with lower doses. The optimal dose of TXA was set at $30 \mathrm{mg} / \mathrm{kg} \mathrm{bw}$. The plasma levels of TNF- $\alpha$, IL-1, IL-6 and IL-8 in S2 group were significantly decreased compared with the control group, indicating that the use of low doses of TXA can effectively reduce perioperative bleeding without increasing the risk of complications. In conclusion, $30 \mathrm{mg} / \mathrm{kg}$ bw is the optimal dose of TXA showing anti-inflammatory effects at different stages of the systemic inflammatory response induced by surgery.
\end{abstract}

\section{Rezumat}

Acest studiu a avut ca scop investigarea eficacității acidului tranexamic (TXA) în perioada perioperatorie a pacienților supuși unei intervenții chirurgicale de corecție a scoliozei. 355 de pacienți cu scolioză au fost împărțiți în mod aleatoriu în cinci grupuri: 4 experimentale tratate cu doze diferite de TXA $(15,30,45$ și $60 \mathrm{mg} / \mathrm{kgc})$ intravenos, cu 30 de minute înainte de intervenţia chirurgicală și perfuzia susținută cu $15 \mathrm{mg} / \mathrm{kgc} / \mathrm{h}$ TXA de la începutul până la sfârșitul intervenției. Pacienții din grupul martor au primit $30 \mathrm{mg} / \mathrm{kgc}$ soluție de ser fiziologic. Timpul de protrombină (PT), timpul de tromboplastină parțial activat (APTT), fibrinogenul (FIB), timpul de trombină (TT), hemoglobina, trombocitele (PT), pierderea de sânge intraoperator și volumul de drenaj postoperator în toate grupurile au fost determinate înainte și după operație. Nivelurile plasmatice ale factorului de necroză tumorală- $\alpha$ (TNF- $\alpha$ ), interleukina-1 (IL-1), IL-6 și IL-8 au fost măsurate înainte, în timpul și după operație și apoi, s-au înregistrat complicațiile postoperatorii. Doza de $60 \mathrm{mg} / \mathrm{kgc}$ TXA determină o creștere a cazurilor de embolie complicată în comparație cu doze mai mici. Doza optimă de TXA a fost stabilită la $30 \mathrm{mg} / \mathrm{kgc}$. Nivelurile plasmatice ale TNF- $\alpha$, IL-1, IL-6 și IL-8 din grupurile experimentale au fost semnificativ scăzute în comparație cu grupul martor, indicând că utilizarea de doze mici de TXA poate reduce în mod eficient perioperator sângerarea fără a crește riscul de complicații.

Keywords: tranexamic acid, scoliosis, orthopaedics, coagulation function, perioperative period

\section{Introduction}

Thoracic scoliosis is a spinal deformity in which one or more vertebral segments of the spine are bent laterally with vertebral body rotation. This deformity determines appearance changes as unequal shoulder height, bilateral thoracic asymmetry, shoulder blade uplift on one side and depression on the other side [1-3]. Its mild symptoms include fatigue, shoulder and back 
pain and difficulty in concentration; in severe cases, in addition to the above-mentioned symptoms, severe back pain and restricted activities of the thoracic vertebra may occur [4-6]. Currently, the risk of massive haemorrhage that leads to postoperative anaemia that appears during orthopaedic surgery is very high [7-10]. In cases of intraoperative blood loss above $500 \mathrm{~mL}$, severe lifethreatening symptoms can develop leading to decreased blood pressure and reduced packed cell volume, thus, it is essential to avoid bleeding in the perioperative period $[11,12]$. Tranexamic acid (TXA), a synthetic derivative of the amino acid lysine, is an anti-fibrinolytic agent that acts by binding to plasminogen and blocking the interaction of plasmin with fibrin, thereby preventing dissolution of the fibrin clot. TXA has proven to be a cost-effective method in decreasing transfusion rates and avoiding complications associated with low blood volume. Several relevant studies have shown that the use of TXA in surgery can effectively reduce the extracorporeal circulation and intraoperative blood loss during spinal surgery. It reduces bleeding by inhibiting the enzymatic degradation of fibrin blood clots by the serine protease plasmin. During fibrinolysis, plasminogen binds to fibrin via lysing binding sites, where it is converted to the active fibrinolytic enzyme plasmin by tissue plasminogen activator [13]. Lin et al. administered TXA as a bolus of $50 \mathrm{mg} / \mathrm{kg}$ bw after induction and before incision, followed by a continuous infusion of $5 \mathrm{mg} / \mathrm{kg}$ bw/h during the whole procedure until the wound was closed [14]. They found that there were three thromboembolic complications, including one pulmonary embolism and two deep vein thromboses (DVTs), which were all treated successfully with anticoagulation. There were no cases of myocardial infarction, seizure, stroke, or acute renal failure. Slattery et al. review the literature for the use of TXA in spine surgery to better understand its safety profile and optimal dosage [15]. They reported that the most common dose in the literature is a $10 \mathrm{mg} / \mathrm{kg}$ bw loading dose, followed by $1 \mathrm{mg} / \mathrm{kg} \mathrm{bw} / \mathrm{h}$. Besides, initial loading doses vary between 2 and $100 \mathrm{mg} / \mathrm{kg}$ bw, and continuous infusion typically varies between 3 and $10 \mathrm{mg} / \mathrm{kg}$ bw/h. Despite this dosing variation, the mode of administration was always intravenous [16].

Therefore, it is of great significance to obtain an optimal dose of TXA to reduce extracorporeal circulation and intraoperative blood loss at the perioperative period without causing complications in patients undergoing scoliosis correction surgery.

This study aimed to assess the efficacy of preoperative application of TXA for patients undergoing scoliosis correction surgery.

\section{Materials and Methods}

\section{Patients}

In the present study, 355 patients with scoliosis, who underwent scoliosis correction surgery in The Second
Affiliated Hospital of Jiamusi University from January 30,2017 , to January 30, 2019, were recruited. They were divided into five groups using the random number table method, 71 patients per group: experimental group 1 ( $\mathrm{S} 1 ; 36$ males and 35 females; a range of age, 21 - 68 years old), experimental group 2 (S2; 43 males and 28 females; a range of age, 24 - 65 years old), experimental group 3 (S3; 29 males and 42 females; a range of age, 22 - 68 years old), experimental group 4 (S4; 25 males and 46 females; a range of age, 24 - 64 years old) and control group (D0; 34 males and 27 females; a range of age, 25 - 70 years old). The study was approved by the Ethics Committee of The Second Affiliated Hospital of Jiamusi University, China. The patients signed the written informed consent form before commencing the study.

Inclusion criteria: patients aged $\geq 20$ years old; patients with normal liver and kidney functions; patients with normal coagulation function before surgery; patients with no history of taking anticoagulant drugs.

Exclusion criteria: patients with poor compliance with therapy and those who were unable to complete the examination; patients with renal insufficiency; patients with contraindications to the use of TXA; patients with chronic diseases; or patients with genetic blood disorders.

\section{Surgical procedures}

All patients were prohibited to drink water $10 \mathrm{~h}$ before surgery. Peripheral vein access was opened during surgery and left radial artery catheterization was performed. All patients received an intravenous injection of $0.05 \mathrm{mg} / \mathrm{kg}$ bw midazolam (Jiangsu Nhwa Pharmaceutical Co., Ltd., Xuzhou, China), $0.5 \mu \mathrm{g} / \mathrm{kg}$ bw sufentanil (Jiangsu Nhwa Pharmaceutical Co., Ltd., Xuzhou, China), $1.5 \mathrm{mg} / \mathrm{kg}$ bw propofol (Jiangsu Hengrui Pharmaceutical Co., Ltd., Nanjing, China) and $0.2 \mathrm{mg} / \mathrm{kg}$ bw cisatracurium (Jiangsu Hengrui Pharmaceutical Co., Ltd., Nanjing, China) for anaesthesia. Then, a clinical single-chamber dual-capsule endotracheal tube was constructed and connected to the ventilator. The tidal volume was set to $7 \sim 10 \mathrm{~mL} / \mathrm{kg}$ bw, the respiratory rate was $12 \sim 14$ times/min and the patient was placed in a prone position. During the surgery, $5 \mathrm{mg} / \mathrm{kg}$ bw/h propofol, $0.2 \mu \mathrm{g} / / \mathrm{kg} \mathrm{bw} / \mathrm{min}$ sufentanil and $0.8 \mu \mathrm{g} / \mathrm{kg} \mathrm{bw} / \mathrm{min}$ cisatracurium were used. Furthermore, 1 - $3 \mathrm{mg} / \mathrm{kg}$ bw cisatracurium was administered for $30 \mathrm{~min}$ until $0.5 \mathrm{~h}$ before the end of surgery. It is noteworthy to maintain arterial pressure in the range of $80-90 \mathrm{mmHg}$ during surgery.

TXA treatment

Patients in S1, S2, S3 and S4 groups received an intravenous injection of 15, 30, 45 and $60 \mathrm{mg} / \mathrm{kg}$ bw TXA (Changchun Tiancheng Pharmaceutical Co., Ltd., Changchun, China) for 20 min starting $0.5 \mathrm{~h}$ before the operation, respectively, and sustained infusion of $15 \mathrm{mg} / \mathrm{kg}$ bw/h was maintained from the beginning until the end of the operation. Patients in the D0 group received the same volume of normal saline as control. 
Blood sample collection and serum factor detection During the operation, $6 \mathrm{~mL}$ arterial blood was collected on heparin anti-coagulant before cardiopulmonary bypass (CPB), during $\mathrm{CPB}$ and $5 \mathrm{~h}$ after $\mathrm{CPB}$.

The arterial blood was centrifuged at $3000 \mathrm{rpm}$ for 30 min and the supernatant was extracted and stored at $-20^{\circ} \mathrm{C}$. The levels of tumour necrosis factor- $\alpha$ (TNF- $\left.\alpha\right)$, interleukin-1 (IL-1), interleukin-6 (IL-6), interleukin-8 (IL-8) and interleukin-10 (IL-10) in blood samples were detected by double-antibody sandwich enzymelinked immunosorbent assay according to manufacturer instructions (Beijing Zhongshan Jinqiao Biological Co., Ltd., Beijing, China). Briefly, the coated plate was incubated at $37^{\circ} \mathrm{C}$ for $0.5 \mathrm{~h}$ and then, the sealing film was removed and dried. Each hole was washed with the concentrated washing solution (Beijing Zhongshan Jinqiao Biological Co., Ltd., Beijing, China) 5 times in a row. Then $55 \mu \mathrm{L}$ of enzyme-labelled reagent (Beijing Zhongshan Jinqiao Biological Co., Ltd., Beijing, China) was added to each hole and the steps before were repeated. Then $55 \mu \mathrm{L}$ of chromogenic agent $\mathrm{A}$ (Beijing Zhongshan Jinqiao Biological Co., Ltd., Beijing, China) and $55 \mu \mathrm{L}$ of chromogenic agent B (Beijing Zhongshan Jinqiao Biological Co., Ltd., Beijing, China) were added to each hole, mixed by shocking and colour development was performed at $37^{\circ} \mathrm{C}$ for $20 \mathrm{~min} .55 \mu \mathrm{L}$ of termination fluid was added to each hole (Beijing Zhongshan Jinqiao Biological Co., Ltd., Beijing, China) to stop the colour reaction. The absorbance of each hole was measured at a wavelength of $550 \mathrm{~nm}$ within $20 \mathrm{~min}$ after the colour reaction was stopped. Immunohistochemistry (IHC)

Peripheral blood mononuclear cells (PBMCs) of all patients were stained by IHC. The phosphoric acid buffer solution (Beijing Zhongshan Jinqiao Biological Co., Ltd., Beijing, China) was used to dilute $3 \mathrm{~mL}$ blood at a ratio of 1:1 and it was centrifuged at 3000 rpm for $30 \mathrm{~min}$ to collect a layer of milky white liquid suspended in the middle of the test tube. The PBMC sample was soaked at $25^{\circ} \mathrm{C}$ for $30 \mathrm{~min}$ with $35 \%$ hydrogen peroxide (Beijing Zhongshan Jinqiao Biological Co., Ltd., Beijing, China), and then, it was washed three times with distilled water. Bovine serum albumin (BSA) (Beijing Zhongshan Jinqiao Biological Co., Ltd., Beijing, China) was added and incubated at $25^{\circ} \mathrm{C}$ for $25 \mathrm{~min}$, and then, diluted primary anti-goat anti-rabbit IgG antibody (Beijing Zhongshan Jinqiao Biological Co., Ltd., Beijing, China) was added. It was incubated at room temperature for about $3 \mathrm{~h}$ and washed three times with phosphate-buffered saline (PBS). Secondary biotinylated goat anti-rabbit IgG antibody (Beijing Zhongshan Jinqiao Biological Co., Ltd., Beijing, China) was added and incubated at $25^{\circ} \mathrm{C}$ for $30 \mathrm{~min}$. Finally, the samples were incubated with 3,3'-diaminobenzidine (DAB) (Zhongshan Jinqiao Biological Co., Ltd., Beijing, China) at room temperature for $20 \mathrm{~min}$, and then, rinsed with tap water for colour development. Interpretation criteria were adopted as previously described [17]. The semi-quantitative method was adopted for analysis. For the number of positive cells: 0 and 1 point indicated the positive cells were less than $10 \%$ and $10 \%-25 \%$, respectively; 2 and 3 points suggested the positive cells were $25 \%-75 \%$ and higher $75 \%$, respectively. For the staining intensity: 0 mean the cells were not stained and 1, 2 and 3 indicate that the cells were stained into light yellow, brownish yellow and brownish-purple, respectively. Then, points of the two indicators were added together: 0 referred to negative (-), 1 - 4 point(s) referred to weakly positive $(+), 5-8$ points indicated positive $(++)$ and $9-12$ points suggested strongly positive $(+++)$. Observation indicators

The basic data of the patients from the five groups (age, height, weight, body temperature, number of spinal segments, operative time and infusion volume) were collected. The blood coagulation function indicators were detected and recorded before and after the surgery with the PUN-2048B (Prelong New Technology Co., Ltd., Beijing of China), including prothrombin time (PT), activated partial thromboplastin time (APTT), Fibrinogen (FIB) and thrombin time (TT). After the set of the optimal dose of TXA was set, plasma levels of TNF-a, IL-1, IL-6 and IL-8 were detected in S2 group and D0 group before, during and after the operation.

The preoperative and postoperative haemoglobin was detected by latex-enhanced turbidimetric immunoturbidimetric assay (LETIA) and PT level was detected by low cytometry (FCM). Besides, the intraoperative blood loss and postoperative drainage volume in 24 hours were recorded. Follow-up was conducted and patients were admitted to the ward $24 \mathrm{~h}$ postoperation to identify the symptoms related to wrong anaesthesia and whether there were concurrent vascular embolism, anaemia and other adverse events and the number of patients was recorded as well.

Statistical analysis

The data were statistically analysed by SPSS 19.0 software (IBM, Armonk, NY, USA) and the measured data were expressed as mean \pm standard deviation $(\dot{\mathrm{x}} \pm \mathrm{s})$. The Student's t-test was used for making a comparison between each pair of groups. $\mathrm{p}<0.05$ was considered statistically significant.

\section{Results and Discussion}

\section{Basic data of patients}

There were no statistically significant differences in age, height, weight, body temperature, number of spinal segments, operative time and infusion volume between each pair of groups $(p>0.05)$ (Figure 1). 

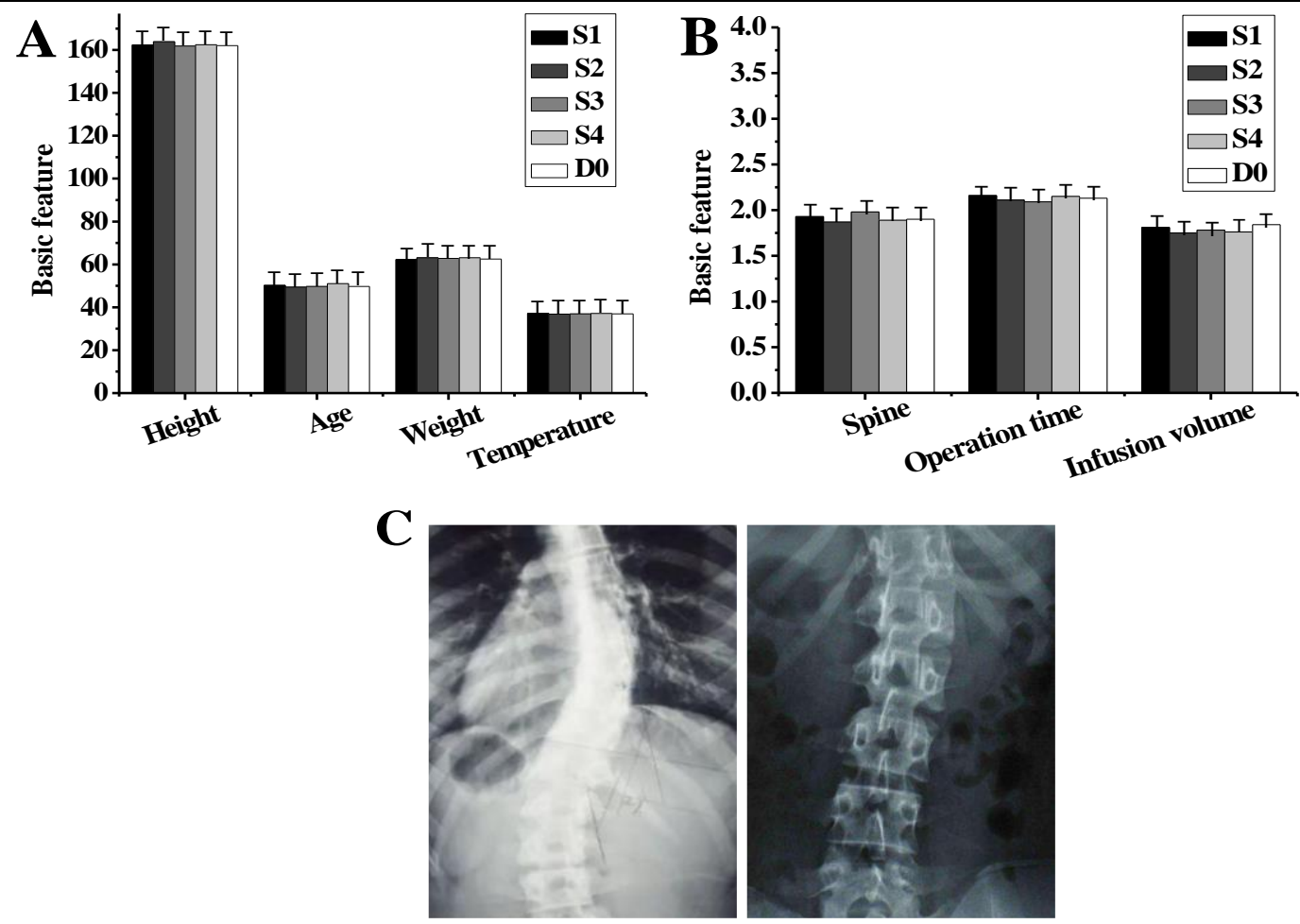

Figure 1.

Comparison of basic data of patients among S1, S2, S3, S4 and D0 groups

A: the patients' age, height, weight and body temperature; B: the number of spinal segments, operative time and infusion volume; C: a patient's CT image

Levels of coagulation function before and after the surgery

There was no statistically significant difference in levels of PT, APTT, FIB and TT before surgery in each group ( $p>0.05)$. In the S1, S2, S3 and D0 groups, the levels of PT, APTT and TT after surgery were noticeably higher than those before surgery and the postoperative level of FIB was markedly lower than the preoperative level $(\mathrm{p}<0.05)$. Postoperative levels of APTT, FIB and TT in the S4 group were significantly higher than those preoperatively and PT level was markedly lower than the preoperative level $(\mathrm{p}<0.05)$. Postoperative levels of PT, APTT and TT in S1 group were significantly higher than those in S2, S3 and S4 groups, and the level of FIB was remarkably lower than that in S2, S3 and S4 groups ( $\mathrm{p}<0.05$ ). Postoperative levels of PT and APTT in the S2 group were significantly higher than those in S3 and S4 groups, and FIB level was notably lower than that in $\mathrm{S} 3$ and S4 groups $(\mathrm{p}<0.05)$. Postoperative PT level in S3 group was dramatically higher than that in the S4 group, and FIB level was significantly lower than that in the $\mathrm{S} 4$ group $(\mathrm{p}<0.05)$. The increased levels of PT, APTT and TT in the D0 group were markedly higher than those in S2, S3 and S4 groups $(\mathrm{p}<0.05)$ (Figure 2).
There was no statistically significant difference in levels of PT, APTT, FIB and TT before surgery in each group $(\mathrm{p}>0.05)$. In the $\mathrm{S} 1, \mathrm{~S} 2, \mathrm{~S} 3$ and D0 groups, the levels of PT, APTT and TT after surgery were noticeably higher than those before surgery and the postoperative level of FIB was markedly lower than the preoperative level $(\mathrm{p}<0.05)$. Postoperative levels of APTT, FIB and TT in the S4 group were significantly higher than those preoperatively and PT level was markedly lower than the preoperative level ( $p<0.05$ ). Postoperative levels of PT, APTT and $\mathrm{TT}$ in $\mathrm{S} 1$ group were significantly higher than those in S2, S3 and S4 groups, and the level of FIB was remarkably lower than that in S2, S3 and S4 groups $(p<0.05)$. Postoperative levels of PT and APTT in the $\mathrm{S} 2$ group were significantly higher than those in S3 and S4 groups, and FIB level was notably lower than that in $\mathrm{S} 3$ and $\mathrm{S} 4$ groups $(\mathrm{p}<0.05)$.

Postoperative PT level in S3 group was dramatically higher than that in the S4 group, and FIB level was significantly lower than that in the S4 group $(\mathrm{p}<0.05)$. The increased levels of PT, APTT and TT in the D0 group were markedly higher than those in $\mathrm{S} 2, \mathrm{~S} 3$ and $\mathrm{S} 4$ groups $(\mathrm{p}<0.05)$ (Figure 2). 

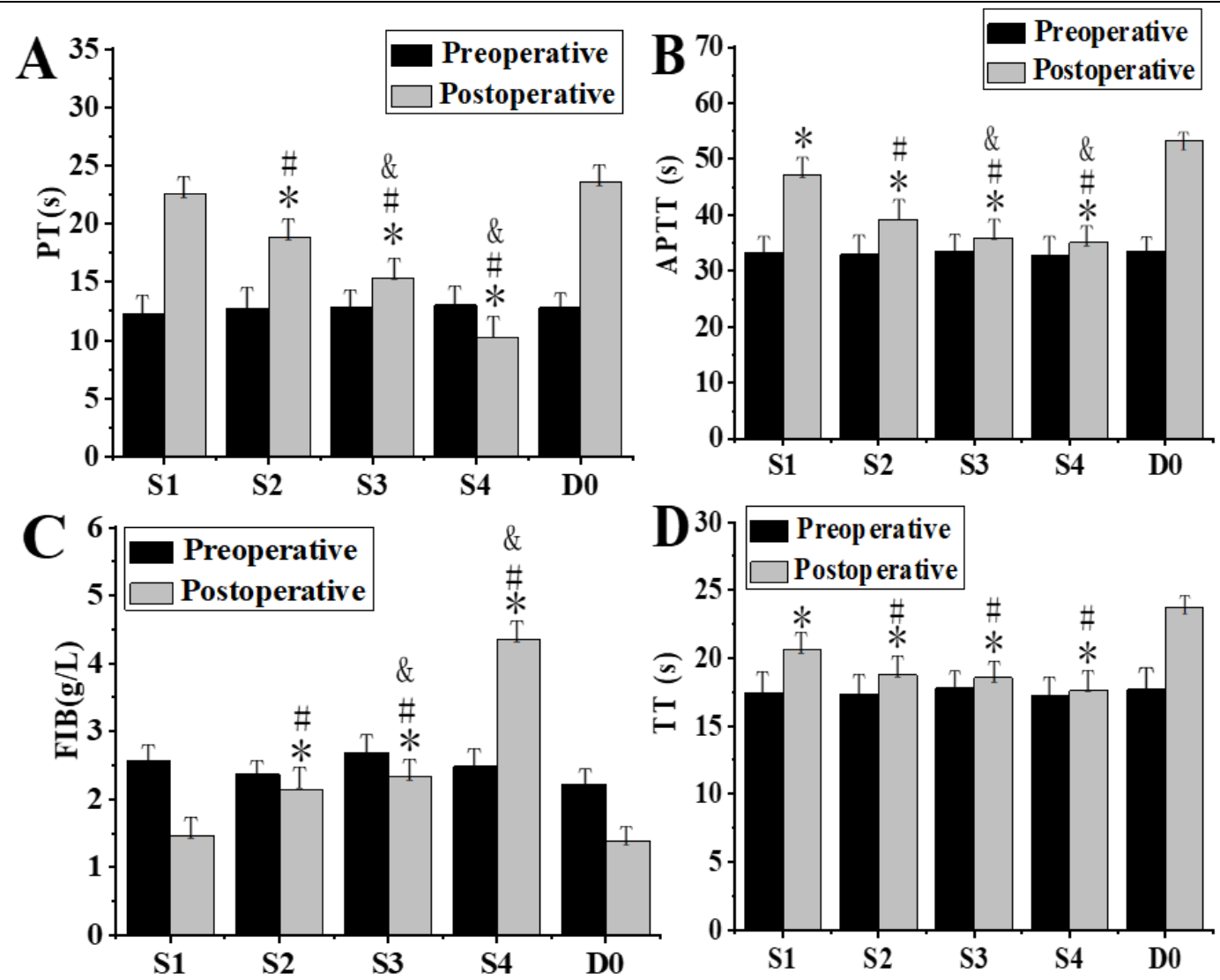

Figure 2.

Levels of coagulation function before and after operation among S1, S2, S3, S4 and D0 groups

A: the PT level before and after the operation; B: the APTT level before and after the operation; C: the FIB level before and after the operation; D: the TT level before and after the operation;

$* \mathrm{p}<0.05$ compared with D0; \# $\mathrm{p}<0.05$ compared with S1; \& $\mathrm{p}<0.05$ compared with S2
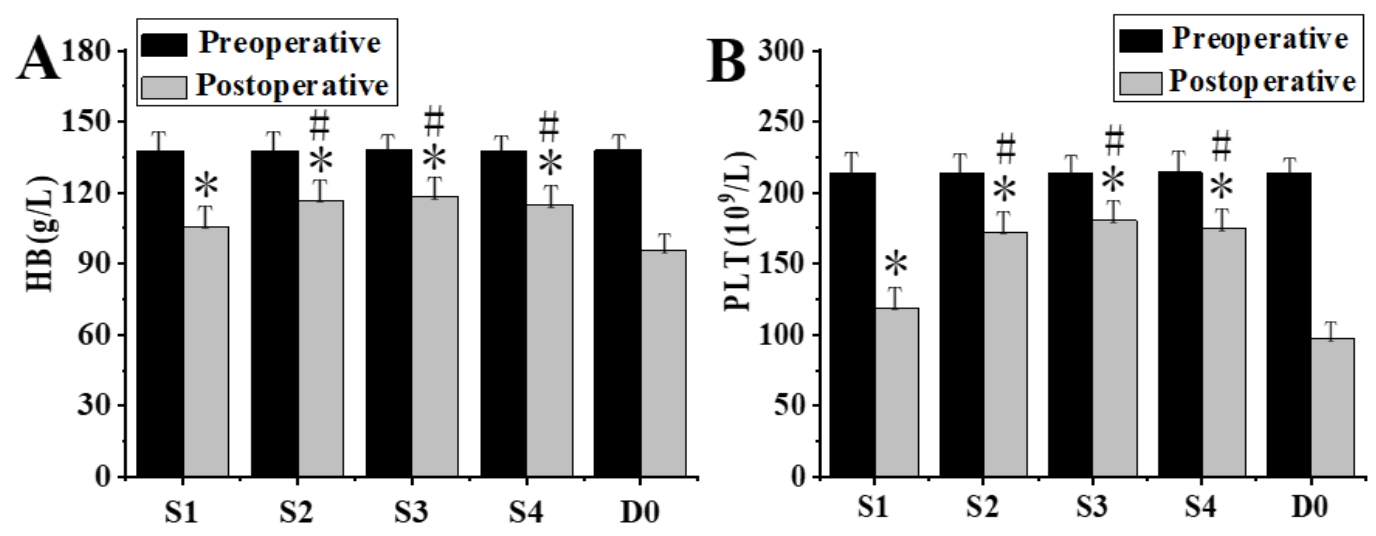

Figure 3.

Changes in haemoglobin and PT levels before and after the operation in S1, S2, S3, S4 and D0 groups

A: the haemoglobin level before and after the operation; B: the PT level before and after the operation $* \mathrm{p}<0.05$ compared with D0; \# $\mathrm{p}<0.05$ compared with $\mathrm{S} 1$

Changes in haemoglobin and PT levels before and after the operation

There was no statistically significant difference between the groups in the levels of haemoglobin and PT before the operation $(p>0.05)$. The postoperative levels of haemoglobin and PT in each group were significantly lower than those before the operation $(p>0.05)$. The postoperative levels of haemoglobin and PT in the
D0 group were noticeably lower than those in the S1, S2, S3 and S4 groups. Postoperative levels of haemoglobin and PT in the $S 1$ group were dramatically lower than those in S2, S3 and S4 groups, and significantly higher than those in the D0 group ( $\mathrm{p}<$ 0.05). There was no significant difference in postoperative levels of haemoglobin and PT between each pair of S1, S2 and S3 groups ( $p>0.05$ ). Postoperative 
levels of haemoglobin and PT in S1, S2 and S3 groups were significantly higher than those in the D0 group $(\mathrm{p}<0.05)$ (Figure 3).

Intraoperative blood loss and postoperative drainage volume

Intraoperative blood loss and postoperative drainage volume in the D0 group were significantly increased compared with the other groups ( $\mathrm{p}<0.05)$. The intraoperative blood loss and postoperative drainage volume were significantly increased in the $\mathrm{S} 1$ group compared with S2, S3 and S4 groups ( $<<0.05)$. There was no statistically significant difference in intraoperative blood loss and postoperative drainage volume between S2 and $\mathrm{S} 3$ group ( $\mathrm{p}>0.05)$. The intraoperative blood loss and postoperative drainage volume in the $S 4$ group were significantly decreased compared with S2 and $\mathrm{S} 3$ groups $(\mathrm{p}<0.05)($ Figure 4$)$
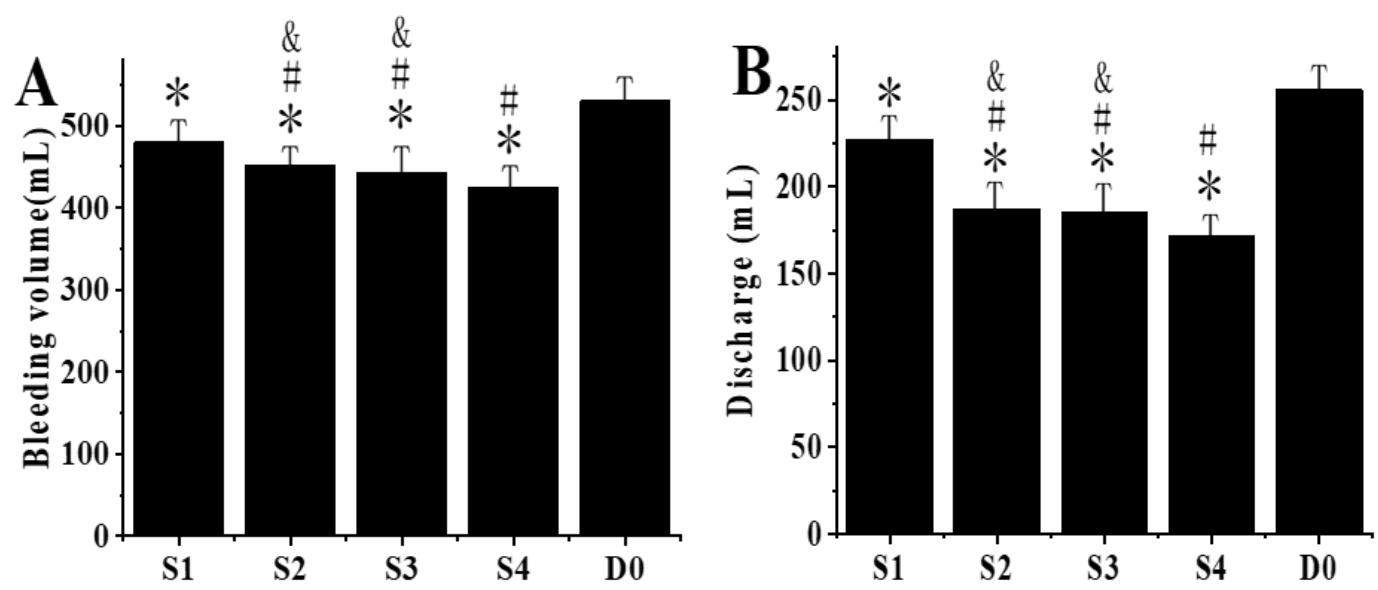

Figure 4.

Intraoperative blood loss and postoperative drainage volume in S1, S2, S3, S4 and D0 groups

A: the intraoperative blood loss; B: the postoperative drainage volume

$* \mathrm{p}<0.05$ compared with D0; \# $\mathrm{p}<0.05$ compared with $\mathrm{S} 1 ; \& \mathrm{p}<0.05$ compared with S4
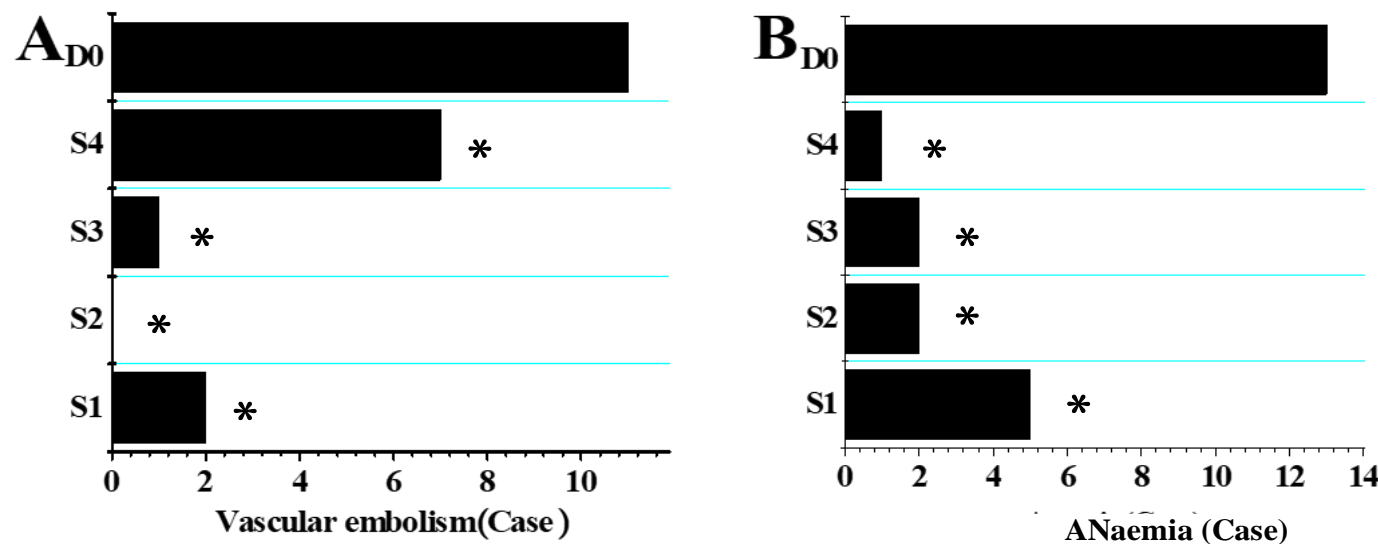

Figure 5.

Postoperative complications in S1, S2, S3, S4 and D0 groups

A: the postoperative vascular embolization; $\mathrm{B}$ : the postoperative anaemia $* \mathrm{p}<0.05$ compared with D0

\section{Postoperative complications}

As shown in Figure 5, in the S1 group, 2 patients were complicated with postoperative vascular embolism and 5 patients were complicated with anaemia. There was no case with postoperative vascular embolism and 2 cases with postoperative anaemia in S2 group. One patient in the S3 group was complicated with vascular embolism and 2 with anaemia postoperatively. In the S4 group, there were 7 cases of postoperative vascular embolism and 1 case of postoperative anaemia. In the D0 group, 11 patients were complicated with vascular embolism and 13 with anaemia. The number of cases with postoperative vascular embolism and anaemia in the D0 group was significantly higher than that in other experimental groups. The number of patients in the S4 group with concurrent vascular embolism was significantly increased compared with those in the S1, S2 and S3 groups. The number of patients with concurrent anaemia in the $\mathrm{S} 1$ group was significantly increased compared with those in S2, S3 and S4 groups. 
Comparing plasma levels of TNF- $\alpha, I L-1, I L-6$ and IL-8 between $S 2$ group and control group

Since the TXA dose of $30 \mathrm{mg} / \mathrm{kg}$ bw was found as the optimum dose, the plasma levels of TNF- $\alpha$, IL- 1 , IL-6 and IL-8 were compared between S2 group and the control group at different periods. There was no significant difference in TNF- $\alpha$, IL-1, IL-6 and IL-8 in the $\mathrm{S} 2$ group and D0 group before surgery ( $\mathrm{p}>0.05)$. The intraoperative and postoperative period TNF- $\alpha$, IL-1, IL-6 and IL-8 in the S2 group were significantly lower than those in the control group $(p<0.05)$ (Figure 6).
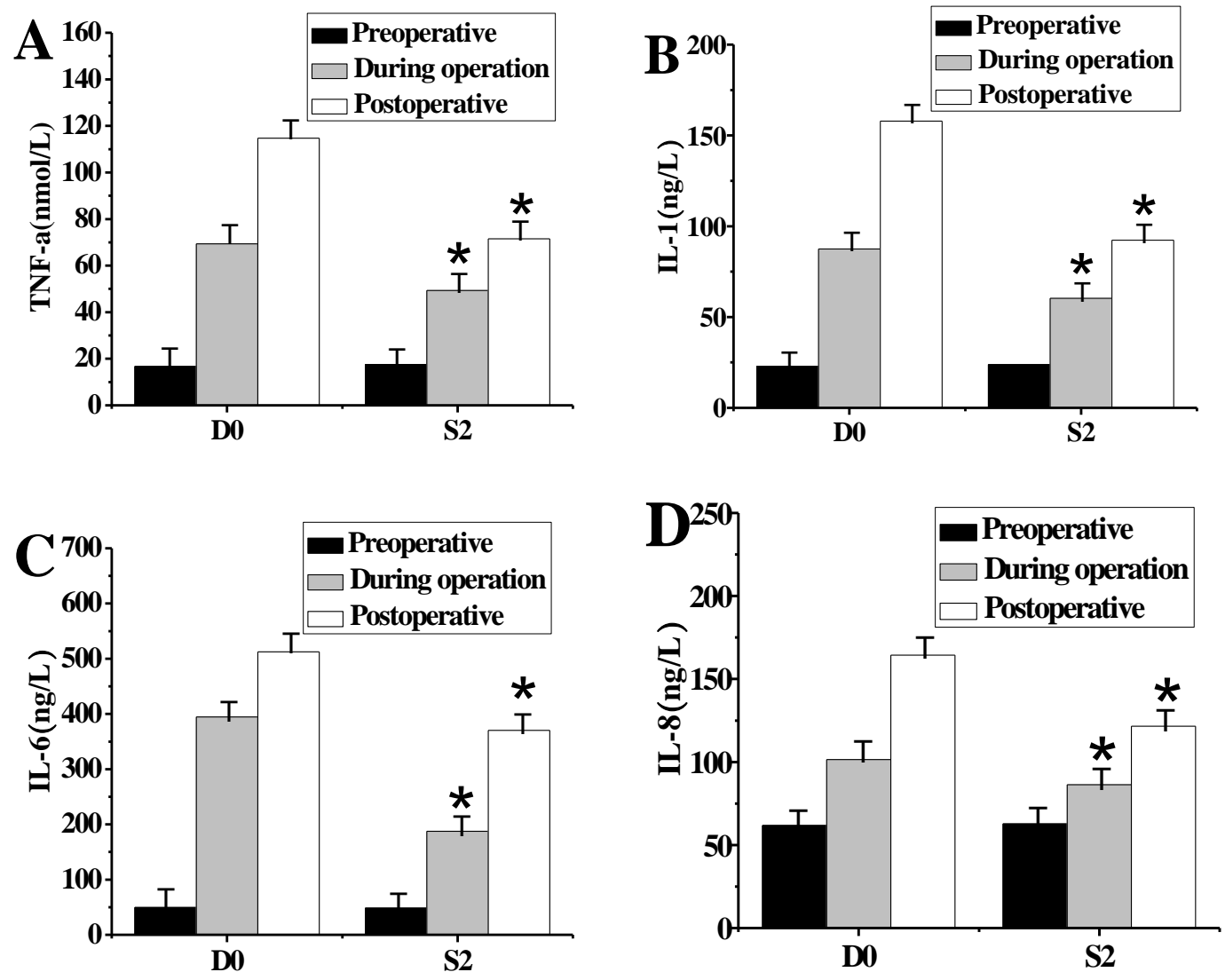

Figure 6.

Comparing plasma levels of TNF- $\alpha$, IL-1, IL-6 and IL-8 between S2 group and control group A: the plasma level of TNF- $\alpha$; B: the plasma level of IL-1; C: the plasma level of IL-6; D denotes the plasma level of IL-8 $* \mathrm{p}<0.05$ compared with the D0
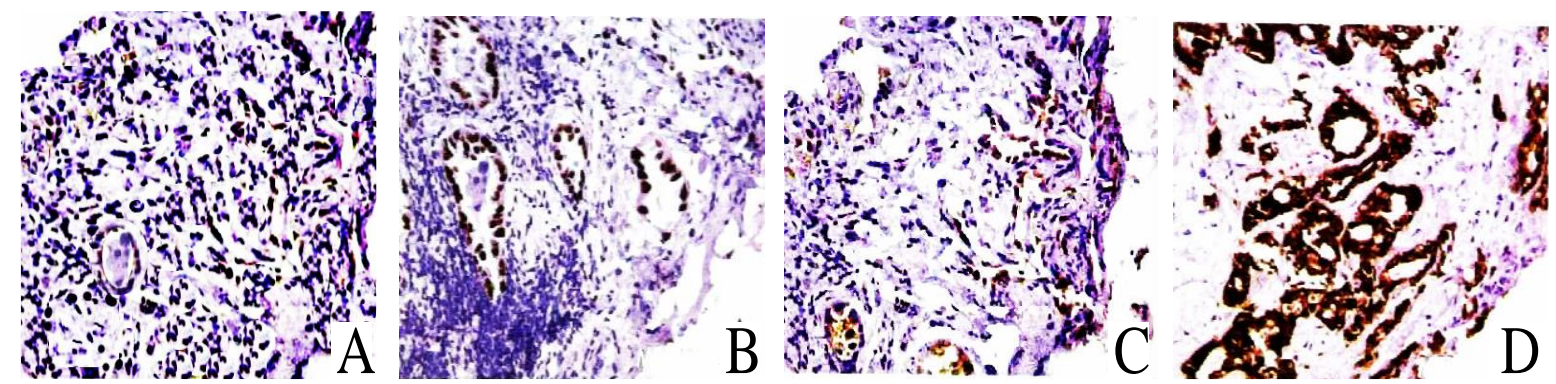

Figure 7.

Results of IHC in S2 and D0 group

A: the results (-) of a male patient (aged 31) in S2 group; B: the results (-) of a male patient (aged 56) in S2 group; C: the result (++) of a female patient (aged 35) from S2 group; D: the result (+++) of a male patient (aged 38) from D0 group

Peripheral blood mononuclear cells (PBMCs) expression in the $S 2$ group and DO group

The immunohistochemical staining showed that in the $\mathrm{S} 2$ group it was a prevalence of negative expression of PBMCs stained coloured in blue (Figures 7A and
7B). In the D0 group it was a higher expression of PBMCs stained in brownish-purple (Figure 7C). In some patients it is observed a large number of cells stained into brownish-purple, mixed inflammatory cell infiltration in the lamina propria of mucosa, along 
with some oval cells with transparent cytoplasm, mixed with a large number of eosinophils (Figure 7D). The quantitative comparison of the positive expression rate of PBMCs in patients from S2 group and D0 group illustrated that the positive expression rate of patients in group S2 (10.47\%) was significantly decreased compared with those in group D0 $(67.43 \%)(\mathrm{p}<0.05)$.

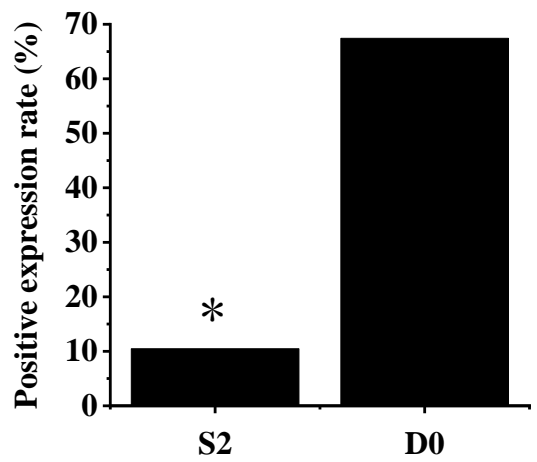

Figure 8.

Comparison of the positive expression rate of patients in the S2 group and D0 group

$* \mathrm{p}<0.05$ compared with the D0 group

Scoliosis correction surgery is complicated and timeconsuming and a patient's body often bleeds heavily during the whole process. Previous researches reported that the perioperative use of TXA can effectively reduce the amount of blood loss, while there is no unified standard for the optimum dosage of TXA [17-19]. Therefore, in the present study, the TXA dose was set to $15,30,45$ and $60 \mathrm{mg} / \mathrm{kg}$ bw. The results showed that the increased levels of PT, APTT and TT in the control group were significantly increased compared with the levels from S2, S3 and S4 groups ( $<<0.05)$, and the decrease of postoperative FIB levels was significantly increase compared with those in S2, S3 and S4 groups $(\mathrm{p}<0.05)$, which was consistent with Yuan et al.'s findings [20]. This is associated with the ability of TXA that is a lysine analogue, to bind to the enzyme activator, and effectively inhibit the activation of the enzyme, thereby reducing the activity of plasminogen. Besides, postoperative levels of PT, APTT and TT in S1 group were significantly higher compared with those in S2, S3 and S4 groups, and the level of FIB was significantly lower compared with those in S2, S3 and S4 groups ( $p<0.05$ ), which suggested that a dose of $15 \mathrm{mg} / \mathrm{kg}$ bw TXA was not enough to achieve the optimal clinical effect during the perioperative period [21]. Several scholars pointed out that TXA can inhibit the activation of PT and thus play a role in PT protection. In the current study, it was found that the postoperative levels of haemoglobin and PT in the control group were remarkably lower than those in the S1, S2, S3 and S4 groups ( $<<0.05)$, which was in agreement with previous studies. It was further demonstrated that TXA can bind to a spot on the PT membrane and also bind more strongly than fibrinogen or fibrin [22].

Intraoperative blood loss and postoperative drainage volume are of great significance to assess the blood protection effect during the operation. In the current research, it was unveiled that the intraoperative blood loss and postoperative drainage volume in the control group were markedly higher than those in all experimental groups ( $\mathrm{p}<0.05)$, which was consistent with Fauzi et al. results [23]. It indicated that TXA could effectively reduce the bleeding and blood transfusion in patients during scoliosis correction surgery. The intraoperative blood loss and postoperative drainage volume in the $S 1$ group were notably higher than those in S2, S3 and S4 groups ( $p<0.05$ ). Also, there was no statistically significant difference in intraoperative blood loss and postoperative drainage volume between the $\mathrm{S} 2$ group and $\mathrm{S} 3$ group $(\mathrm{p}>0.05)$. Additionally, to analyse the safe application of TXA, follow-up was conducted and the postoperative complications in all the groups were recorded. The results of the current research uncovered that there were noticeably more cases of postoperative vascular embolism and anaemia in the control group than those in other experimental groups, which indicated that TXA was safe and feasible for surgical application, and also did not increase the risk of concurrent vascular embolism events [25]. However, the number of patients in the $\mathrm{S} 4$ group with complicated vascular embolism was markedly higher than that in the S1, S2 and S3 groups, which reflected that the high dose of TXA administered at $60 \mathrm{mg} / \mathrm{kg}$ bw may lead to the risk of postoperative complicated vascular embolism [25-28]. Also, plasma levels of TNF- $\alpha$, IL- 1 , IL- 6 and IL- 8 were compared before and after the operation in the $\mathrm{S} 2$ group and the control group, and it was disclosed that the levels of TNF-a, IL-1, IL-6 and IL-8 in the S2 group were significantly decreased compared with those in the control group $(\mathrm{p}<0.05)$, which indicated that TXA had an antiinflammatory effect on different stages of the systemic inflammatory response induced by surgery, possibly because TXA can indirectly play an anti-inflammatory role by protecting inflammation-related PTs [27].

\section{Conclusions}

In the current research, the clinical significance of the preoperative application of TXA in patients undergoing scoliosis correction surgery was analysed by setting different doses of TXA. However, the sample size was relatively small and the follow-up period was short. In summary, TXA can effectively reduce perioperative bleeding in patients undergoing scoliosis correction surgery without increasing the risk of postoperative complications, and it can play an anti-inflammatory role at different stages of systemic inflammatory response. TXA at a dose of $30 \mathrm{mg} / \mathrm{kg}$ bw is the optimum dose for blood protection. We will conduct a large 
sample size with long-term follow-up on patients with scoliosis and improve the efficacy and safety analysis of TXA.

\section{Conflict of interest}

The authors declare no conflict of interest.

\section{References}

1. Bachmann KR, Lu E, Novicoff WM, Newton PO, Abel MF, Buckland A, Samdani A, Jain A, Lonner B, Yaszay B, Reilly C, Hedequist D, Clements D, Miyanji F, Shufflebarger H, Flynn J, Asghar J, Thiong JMM, Pahys J, Harms J, Bachmann K, Lenke L, Glotzbecker M, Kelly M, Vitale M, Marks M, Gupta M, Fletcher N, Cahill P, Sponseller P, Gabos P, Newton P, Betz R, Lehman R, George S, Hwang S, Shah S, Errico T, Upasani V, Harms Study Group, Harms Study Group Investigators, The Lumbosacral Takeoff Angle Can Be Used to Predict the Postoperative Lumbar Cobb Angle Following Selective Thoracic Fusion in Patients with Adolescent Idiopathic Scoliosis. J Bone Joint Surg Am., 2020; 102(2): 143-150.

2. Ageu LŞ, Levai CM, Andreescu NI, Grigoraş ML, Hogea LM, Chiriac DV, Folescu R, Bredicean AC, Nussbaum LM, Enătescu VR, Poroch V, Lupu V, Puiu M, Nussbaum LA, Modern molecular study of weight gain related to antidepressant treatment: clinical implications of the pharmacogenetic testing. Rom J Morphol Embryol., 2018; 59(1): 165-173.

3. Solla F, Clément JL, Cunin V, Bertoncelli CM, Fière V, Rampal V, Patient-specific rods for thoracic kyphosis correction in adolescent idiopathic scoliosis surgery: Preliminary results. Orthop Traumatol Surg Res., 2020; 106(1): 159-165.

4. Lonner BS, Haber L, Toombs C, Parent S, Shah SA, Lenke L, Sucato D, Clements D, Newton PO, Is Anterior Release Obsolete or Does It Play a Role in Contemporary Adolescent Idiopathic Scoliosis Surgery? A Matched Pair Analysis. J Pediatr Orthop., 2020; 40(3): e161-e165.

5. Yang JH, Suh SW, Chang DG, Rib regeneration morphology after thoracoplasty in adolescent idiopathic scoliosis. Spine (Phila Pa 1976), 2020; 45(3): 177-183.

6. Pietton R, Bouloussa H, Vergari C, Skalli W, Vialle R, Rib Cage Measurement Reproducibility Using Biplanar Stereoradiographic 3D Reconstructions in Adolescent Idiopathic Scoliosis. J Pediatr Orthop., 2020; 40(1): 36-41.

7. Floman Y, El-Hawary R, Millgram MA, Lonner BS, Betz RR, Surgical management of moderate adolescent idiopathic scoliosis with a fusionless posterior dynamic deformity correction device: interim results with bridging 5-6 disc levels at 2 or more years of follow-up. $J$ Neurosurg Spine., 2020: 1-7.

8. Li Q, Xiao J, Zhu H, Zheng S, Shi Z, Effects of tranexamic acid administration on recovery after unilateral total knee arthroplasty. Farmacia, 2018; 66(4): 718-724.

9. Feeley I, Hughes A, Cassidy N, Green C, Use of a novel corrective device for correction of deformities in adolescent idiopathic scoliosis. Ir J Med Sci., 2020; 189(1): 203-210.
10. Tauchi R, Kawakami N, Castro MA, Ohara T, Saito T, Morishita K, Yamauchi I, Long-term Surgical Outcomes After Early Definitive Spinal Fusion for Early-onset Scoliosis With Neurofibromatosis Type 1 at Mean Follow-up of 14 Years. J Pediatr Orthop., 2020; 40(1): 42-47.

11. Papacocea T, Popa E, Turliuc D, Papacocea R, The usefulness of dexamethasone in the treatment of chronic subdural hematomas. Farmacia, 2019; 67(1): 140-145.

12. Fan Y, Wang J, Cai M, Xia L, Wang X. The Correlation Between Postoperative Cervical Sagittal Alignment and Spine Sagittal Alignment in Adolescent Idiopathic Scoliosis: A Meta-Analysis. World Neurosurg., 2020; 134: e311-e316.

13. Tsirikos AI, Augustithis GA, McKean G, Karampalis C, Cyanotic Congenital Cardiac Disease and Scoliosis: Pre-Operative Assessment, Surgical Treatment, and Outcomes. Med Princ Pract., 2020; 29(1): 46-53.

14. Lin JD, Lenke LG, Shillingford JN, Laratta JL, Tan LA, Fischer CR, Weller MA, Lehman RAJr, Safety of a High-Dose Tranexamic Acid Protocol in Complex Adult Spinal Deformity: Analysis of 100 Consecutive Cases. Spine Deform., 2018; 6(2): 189-194.

15. Slattery C, Kark J, Wagner T, Verma K, The Use of Tranexamic Acid to Reduce Surgical Blood Loss: A Review Basic Science, Subspecialty Studies, and The Evolution of Use in Spine Deformity Surgery. Clin Spine Surg., 2019; 32(2): 46-50.

16. Bustillo MA, Hussain I, Virk MS, Fu KM, Scharoun $\mathrm{JH}$, Scoliosis correction with one ventricle: A multispecialty approach. World Neurosurg., 2020; 134: 302-307.

17. Țica OA, Țica O, Antal L, Hatos A, Popescu MI, Pantea Stoian A, Bratu OG, Găman MA, Pițuru SM, Diaconu CC, Modern oral anticoagulant treatment in patients with atrial fibrillation and heart failure: insights from the clinical practice. Farmacia, 2018; 66(6): 972-976.

18. Smith JS, Shaffrey CI, Baldus CR, Kelly MP, Yanik E, Lurie JD, Edwards CC, Glassman SD, Lenke LG, Boachie-Adjei O, Buchowski JM, Carreon LY Leah Y. CarreonMD, Gum JL, Crawford III CH, Errico TJ, Lewis SJ, Kim HJ, Ames CP, Bess S, Schwab FJ, Bridwell KH, International Spine Study Group, International Spine Group Study. 19. Adult symptomatic lumbar scoliosis patients have high orthopedic disease burden beyond their spinal deformities: results from a prospective multicenter study. Spine J., 2019; 19 (9, Supplement): S9-S10.

19. Goobie SM, Zurakowski D, Glotzbecker MP, McCann ME, Hedequist D, Brustowicz RM, Sethna NF, Karlin LI, Emans JB, Hresko MT, Tranexamic Acid Is Efficacious at Decreasing the Rate of Blood Loss in Adolescent Scoliosis Surgery: A Randomized PlaceboControlled Trial. J Bone Joint Surg Am., 2018; 100(23): 2024-2032.

20. Yao RZ, Gao WQ, Wang BW, Wang GL, Wu CX, A-Mu YD, Efficacy and safety of tranexamic acid in reducing blood loss of lower extremity osteotomy in peri-acetabulum and high tibia: A systematic review and meta-analysis. Orthop Surg., 2019; 11(4): 545-551.

21. Johnson DJ, Johnson CC, Goobie SM, Nami N, Wetzler JA, Sponseller PD, Frank SM, High-dose versus low-dose tranexamic acid to reduce transfusion 
requirements in pediatric scoliosis surgery. J Pediatr Orthop., 2017; 37(8): e552-e557.

22. Pong RP, Leveque JA, Edwards A, Yanamadala V, Wright AK, Herodes M, Sethi RK, Effect of tranexamic acid on blood loss, D-dimer, and fibrinogen kinetics in adult spinal deformity surgery. J Bone Joint Surg Am., 2018; 100(9): 758-764.

23. Fauzi A, Moelyono A, Tobing SD, Compared to Conventional Dressing Techniques, Tranexamic Acid Injection Provide Better Surgical Outcomes in Spinal Fusion Surgery. Biomed Pharmacol J., 2018; 11(4): 2215-2220.

24. Nazareth A, Shymon SJ, Andras L, Goldstein RY, Kay RM, Impact of tranexamic acid use on blood loss and transfusion rates following femoral varus derotational osteotomy in children with cerebral palsy. J Child Orthop., 2019; 13(2): 190-195.
25. Chevinsky J, Yoshihara H, Blood conservation techniques in scoliosis surgery. Cur Orthop Pract., 2018; 29(5): 449-451.

26. Jakubowski P, Smyk Ł, Puchała Ł, Białkowska J, Current view on vitamin $\mathrm{K} 2$ role in diseases based on clinical trials. Farmacia, 2019; 67(4): 551-556.

27. Luo Y, Zhao X, Releken Y, Yang Z, Pei F, Kang P, Hemostatic and anti-inflammatory effects of carbazochrome sodium sulfonate in patients undergoing total knee arthroplasty: a randomized controlled trial. $J$ Arthroplasty, 2020; 35(1): 61-68.

28. Spataru RI, Popoiu MC, Ivanov M, Foregut duplication cyst associated with esophageal atresia - one-stage neonatal surgical repair. Indian J Surg., 2015; 77 (Suppl. 1): 52-55. 